\title{
ALI IMRON'S RELIGIOUS LANGUAGE COMPREHENSION ON HIS LIFE STORY: SCHEMAS AND SCRIPTS
}

\author{
Lukman Hakim $^{1}$, Joko Arizal ${ }^{2}$ \\ IKIP Budi Utomo Malang \\ Universitas Paramadina Jakarta \\ elha.lukman@gmail.com \\ jkarizal_fa@yahoo.com
}

\begin{abstract}
s
This study discusses Ali Imron's religious language comprehension on his life story. It proposes a problem of question about the schemas and scripts on his religious language understanding and interpreting. The method which applied on this study is the qualitative method, so, the narrative approach is selected as it approach. In addition, the result of this study proposes some significant discussion such as in the schema aspect, there are semantical problem especially in the comprehesion of the word jihad, muhajir, and syahid. The second is understanding the setting. Ali Imron's limited knowledge makes him difficult in comprehend of the social situation which lead him to the battlefield in Afghanistan. The third is his mood. The mood is significant in constructed of his view to the real situation and to the language comprehension. The fourth is the chain of events. This part is the accumulation of his understanding on religious language, setting, and mood which incorporate with his real life situation. And it would be able to strengthen to his belief to be a martyr. Likewise, the script aspect which demonstrate on this part is the conceptual dependency where the manifestation of an incorporation aspect of our knowledge of the world in his conceptual version of our understanding of sentence which would not be possible if his analysis operated with only the syntactic and lexical elements in the sentence. In the end, this study concludes that the backgruond knowledge can lead to errors in understanding language and it appears to Ali Imron's case in interpreting the word of jihad and its comprehension in conceptual meaning.
\end{abstract}

Key Words: Ali Imron, Jihad, Bakground knowledge, Schema, Script.

CPendidikan Bahasa Inggris FPISH IKIP BU Malang

\section{INTRODUCTION}

This study will discuss on Ali Imron's religious language comprehension on his life story discourse within the book Ali Imron Sang Pengebom (The Bomber). Ali Imron is one of the Bali Bomber, with his two old brothers Amrozi and Ali Ghufron, and his best friend Imam Samudra, Ali Imron had involved in Bali bombing and killed many people. The vast majority of the victims were Australian people who visited Bali for holiday. After Bali bombing tragedy on October, 22nd in 2002, Ali Imron were arrested and he is living as a prisoner now. In his jail, he reflected to what had he done, and he expressed his regret into the book.

Previously, before Ali Imron involved to Bali bombing tragedy he had visitited and attended training at military camp in Afghanistan from 1991 to 1996. So, this study will discuss of Imron's life story, mainly his journey and motivation to go to Afghanistan and his involvement to Jamaa'ah Islamiyah group. His motivation to go to Afghanistan is strongly influnced by his family environment where his old brother, Ali Ghufron, had joined to Afghanistan war with his teacher Abdullah Sungkar.

The most interesting subject on his life story is his religious language comprehension on islamic concept which related to war activity. For example, the several concepts of islamic principle like jihad, syahid, and i'dad are interpreted and comprehend by Ali Imron. His interpretation and 
comprehension to those concept, ultimately interesting to analyze through discourse analysis lens.

Refer to some several previuos studies on terrorism mainly since 2001, where the post United States attacked in September 11, the Study on the terrorism is increased widely in the most of the world. In addition On the other hand, especially in Indonesia cases, the effect of the September 112001 in the United States was influenced directly to the national security issue. For example, in 2001, the case of Bali Bombing I, that had killed around 88 Australian citizens and it then was followed by several series suicide bombing attacked in several areas in Indonesia. Likewise, it makes significant national threatening issues for Indonesia.

Similarly, to respon terrorist movement by suicide bombing strategy many Indonesian muslim scholars give statement differently. For example, Luthfi Assyaukanie's stated that the Indonesian muslim radicalist ideas were influenced by the middle eastern muslim radicalist group ideology and it ideas were are diffused in Indonesia (Assyaukanie, 2009: 33). In a similar way, the other of muslim scholar whose apprehensive to the jihad and terrorism issues is Khaled Abou El Fadl. According to him, in the muslim world life today, that the rule of islamic religion was blocked by jihad and terrorism issues because of the public spotlight attention and the most of the popular madia are only presenting jihad and terrorism events (Abou El Fadl, 2005: 220). It means that the issue of jihad and terrorism were not only presented in our real life but it was demonstrated in the popular media as well.

Conversely, based on the study of Alex P. Schmid, where he stated that the study of terrorism can indeed be approached from different diciplines such as criminology, political science, war and peace studies, communication studies or religious studies (Schmid, 2011: 1). Refer to what Schmid stated, therefore, the study on Ali Imron's religious language comprehension is the part of the way to solve the radicalism issue through linguistics lens. The part of the linguistics approach which appropriate to this subject is the discourse analysis approach.

In addition, the discourse analysis approach which apropriate with the subject is a background knowledge subject where it has two main part of branches; they are schema and script. George Yule (2010), pointed out that schema is 'a conventional knowledge structure that exist in memory'. In a similar way, schemas or in other word, schemata is the discourse analysis study which involved the psychological processes of his listeners or readers comprehend. Whereas, a script according to Yule, is 'a conventional knowledge structure in memory for the series of actions involved in events'. Therefore, studying on Ali Imron's comprehension to religious language in his life story through schemas and scripts perspective is being essential in discourse analysis study. While the problems which proposed on this study are how are the role of schema and script on Ali Imron's religious language and how is Ali Imron understanding and interpreting it.

\section{Method}

This study apply qualitative method where narrative research is chosen as it approaches. According to Victor Jupp (2006: 186), in the human sciences, narrative research is 'the term refers to a family of approaches to diverse kinds of text, which have in common a storied form'. In addition, Creswell (2007: 55) points out that the 
types of narratives studies are; a biographical study, autobiography, a life history, and an oral history'. Refer to Creswell statement, this study is a part of the life history. So, the main subject of the study mainly concern to Ali Imron's text life history within the book Ali Imron Sang Pengebom (The Bomber).

\section{Procedur and Data Sources}

The main data sources is gathered from the book Ali Imron Sang Pengebom (The Bomber) and refer to Creswell (2007: 54), the narrative analysis approach is selected 'to construct of events or happenings and then configure them into a story using a plot line'. This approach and the procedur stages is usefull to find a single or multiple episodes or private situations of Ali Imron's life.

\section{Data Collection and Analysis}

The data collected on the transcriping processes such as constructing an event, reconstruct of the story into a plot line. Then, to begin analysis data is reading the data collected through 'SQ3R' stages, they are; Survey, Questions, Read, Recall, and Review. Finally, the data is interpreting through coding process.

\section{Ali Imron's Short Biography}

Ali Imron was born in Lamongan East Java Indonesia on January 2, 1970. He is the youngest of 6 siblings. Besides, he is also the younger brother of Ali Ghufron and Amrozi. Ali Imron comes from the middle class muslim family. It can be seen from Ali Imron's educational background from the beginning of his basic education in Elementary Islamic School up to Senior Islamic High School. He also had time to follow his brother, Ali Ghufron, studying at Ngruki Islamic Boarding School, in Surakarta Central Java. Eventhough it didn't last long time and it only around one month, but it was meaningfull experience for Ali Imron. So far, he continued his education at Muhammadiyah Senior High School in Islamic Boarding School in Karang Asem Paciran Lamongan East Java up to his graduation in 1991 .

However, before Ali Imron had involved to the jihadist group in Afghanistan he was a migrant worker in Malaysia. In addition, through of his brother, Ali Ghufron, in September 1991, he decided to go to Afghanistan to attend the military camp training. So, he took a promise to Abdullah Sungkar before his departure to Afghanistan as his tied loyal commitment to Darul Islam (Islamic State).

In the end, in 1996, Ali Imron return back to Indonesia and he worked as an ustadz (teacher) at Al-Islam Islamic Boarding School Lamongan and it was founded by his brother Chozin. So, two years afterward, he got married and In 1999, Ali Imron went to Ambon based on the Jamaah Islamiyah instruction to fight on jihad for several weeks. In October 12, 2002, Ali Imron, became the first Bali bombing actor that was killed around hundreds of people. Previously, he used to involve in the bombing event series like in the Philippine Embassy in Jakarta and the several churches on the night of Christmas celebration in 2000. Because of Bali bombing tragedy, it leads Ali Imron to prison. Afterwards, in the prison, he regretted his fault and he apologized to whole community to what he had done in Bali with his group.

\section{Finding and Discussion}

Refer to data analysis, there are some significant findings on Ali Imron's interpretation to the religious language on his life story text. His background knowledge which represent in the schema at least it decribes like to the following example. The first, is 
semantical problem, in this part, Ali Imron's interpretation to the word of jihad mainly is full of distorted such as some examples below :

“. . . at the end of 1990, coincided with the mid-year of teaching in Madrasah Aliyah's (Islamic Senior High School) for third class students, my friends whom were living in Pondok Pesantren Karang Asem (Islamic Boarding School of Karang Asem) conducted a study and I took the opportunity to followed the event. In it, there was an explanation from some Ustadz (teachers) who told us about the condition of Muslims around the world including in Palestine, Iraq, and Afghanistan. Additionally, in the event, was inserted watching a video play programme which told on Muslim struggle in some places, such as jihad actions like in Palestine and Afghanistan".

In the discourse, it is clearly that an example of the word jihad meaning in the sentence is fully around on conceptual meaning. Whereas the distortion of meaning where it would be the war when it transforms and connotated with the conflict situation either in Palestina or Afghanistan. Therefore, Ali Imron understanding and interpretation to the word of jihad substantially is incorrect because of he does not recheck to the real concept in islamic teaching. For example, Firestone (1999 : 16) quoted to the Arabic word that the term of jihad is derived from the root j.h.d., where its meaning is to strive, exert oneself, or take extraordinary pains. According to him, Jihad, then, is a verbal noun of the third Arabic form of the root jahada, which is defined classically as "exerting one's utmost power, efforts, endeavors, or ability in contending with an object of disapprobation. Firestone, then, compares the jihad concept with the holy war event in Islam with the classical age in the Arabian muslim context.

Likewise, the similar inappropriate collocation of jihad also appears in the following Ali Imron expression :

"From that moment on, I used to tried to do something better than before. Starting from trying diligently to study, improvin the way of thinking, improvin my daily worship, in order to improve my intention to leave the hometown as muhajir (people who migrate) to reach the field of jihad".

In the sentences, Ali Imron stated that the word jihad is always assumed with the war, while the other word muhajir he interpreted as a moving from his hometown to the battlefield. In contrast, refer to islamic history, the word muhajir is derivation from the word hijrah which mean is migration. It events refer to the prophet Muhammad while he migrate from Mecca to Madina with his followers to avoid agression from his opponents. In contrast, based on the discourse analysis theory, the type of knowledge which is belong to Ali Imron is strongly influenced by his common sense or habitual. In this case, what Ali Imron did through his language and his interpretation was a real description of his idea on the war concept, but his unconcious understanding which applied in the words jihad and muhajir are what Anderson said in George Yule (1988: 247) as ideational scaffolding.

In other part of his life story, Ali Imron is steadily use the word jihad to refer to the war activity, but his language usage elaborated with other word like syahid (martyr). For example: 
"Jihad in the sense of war and its nobelty, as well as syahid (martyrdom) and its nobelty is a stimulation for me to take part in jihad. The virtue of being in the field of jihad is the basis for me to crave for a battlefield somewhere and be able to participate there".

The sentences are clearly enough to understand how Ali Imron's view and his understanding on jihad meaning. Besides, his motivation to be a syahid (martyr) is explicitly stated on the sentence and its tied with the jihad word. So, the interrelated words make Ali Imron's purpose is clear. Conversely, according to Yule (1988: 248), schema can be seen as the organised background knowledge which leads us to expect or predict aspects in our interpretation of discourse. In the case of Ali Imron's interpretation on the discourse of jihad and syahid (martyr) show that his knowledge background is strongly lead him in interpreting and understanding them.

The second is understanding setting, in this section, Ali Imron expresses his cultural shock feeling. It part does where Ali Imron tries to implement his concept principle of jihad to real life, but how he did not have enough knowledge about culture, politics, and military world. What he felt described to the following example:

In my long journey from Karachi to Peshawar, I felt the situation and condition were curious. It was strange like; the weather, the people, the clothes, the stall, the food and bevarage, and everything were curious. After either two or three days journey, finally I arrived in Peshawar Pakistan. In Peshawar, the situation I felt was more curiously because I looked at the
Afghanistan people directly where I only had watched them in a film previously. Then, from Peshawar I moved to Pubby by public transport. Pubbi is the city which prepared by President Ziaul Haq for the muslim assylum seekers stay (the place for hijrah) especially from Afghanistan because of in their country the war were running between Mujahidin group and the Afghanistan Communist regim in Kabul, and the war itself were beginning with Russia until the end the Russia leave Afghanistan in 1988/1989.

His arrival in Pakistan and Afghanistan, which was only offered limited knowledge, made him difficult to understand the complex situation. Previously, he was only followed his old brother Ali Ghufron. Some researchers on terrorism cases like Julie Chernov Hwang (2018: 108), points out that Ali Imron is really adored and aspired his old brother, namely Ali Ghuron. Ali Imron thought that he was only how he would to be like his old brother. So, he believed to everything to what his old brother said.

Therefore, his attitude which only belived to what he knew and listened from his old brother finally it had contrasted to the realilty. What he imagined about battlefiled was extremly contrasted with the reality. Frederic Bartlett (1932) revealed that our memory for discourse was constructive. It process was used information from the encountered discourse, together with knowledge from past experience related to the discourse at hand, to build a mental representation. So, what Ali Imron previously expressed in those sentences are similar with his other statement below : 
Finally, I arraived in Pabbi after two hours approximately I was in public transport. And I felt the stituation in Pabbi was more stanger than in Peshawar. For example, there were many people who brought a weapon everywhere and there were also many imperfection people. Then, I went to the representation office of South East Asia to meet Ustadz Dzulqarnain who was responsible on it. So, while I was taking a rest, Ustadz Dzulqarnain gave me a pseudonym that is Zaid, and since then, my name had changed with Zaid. I stayed in the office only one night because I must to go to Mujahidin Military Academy of Afghanistan for tomorrow with my friend Sawad and under guidence of Sofwan. The location of the military camp was located in Sadda Parachinar, Pakistan.

Ali Imron's first impression to the new situation mainly on the battlefield is clearly represented enough on the previous sentences. For example, how he met directly with the Afghans whom he had only been able to know through pictures and films. Besides, he used to know many civilians whom were carrying firearms and many of them physically were disabled. The situation substantially make Ali Imron's assumption on jihad concept is truly holy war. The following of his impression to the real setting situation is stated below:

After I had arraived in the military camp in Sadda Parachinar, I stayed in one tent together with Imam Samudra, Basir, Sholahuddin, and Hizbullah they were coming from South East Asia. According to them, I was staying in Afghanistan military camp under supervisor Tandzim Ittihad Islami which lead by Syaikh Abdur Robbi Rasul Sayyaf. Eventhough I learned in Mujahidin Military Academy of Afghanistan camp where the vast majority of it students and instructures were from Afghanistan, but the students which came from South East Asia have specific class where the most of my instructures were come from Indonesia and it except only Nasir Abas from Malaysia. The all of the military instuctures must be called an Ustadz.

In this session, Ali Imron explains how was he arrived at the military camp and he tried to make adaptation on it. He also states, how he tried to familiarize the new situation by introduced his new friend in the camp such as Imam Samudra, Basir, Sholahudin, and Hizbullah. From his new friends, Ali Imron was fully realized that he had been in the middle of the real military war camp. In this case, Ali Imron's perception on jihad and syahid (martyr) matched with his background knowledge. Eventhough, according to Hwang (2018: 109), Ali Imron was unable to participate in actual battles but his motivation was highly remained.

Based on this story, especially on the part of the understanding the setting, Ali Imron's feeling began to growth of his consciousness to his environment reality in Afghanistan and Pakistan. In contrast, it had different with his previous imagination that the story of jihad that he knew was the heroic and romantic. In this situation, Ali Imron appeared his incompatency in mastering language because he did not know that either the word or language like the word 
jihad, muhajir, and syahid were foreign language of which he never learned the arabic previously. Refer to linguistics subjec, the words like jihad, muhajir, and syahid are the borrowing words in Bahasa Indonesia (Indonesian Language). According to Yule (2010: 54) it means that the borrowing is the taking over of words from other languages. Therefore, the development of the borrowing in Bahasa Indonesia today is in line with the spread of Islam and the politics of the middle east situation.

The third is mood, a mood is the state of mind or spirits. In the following discourse, Ali Imron expressed how was his jihad understanding then moving his mood and motivation to go to Afghanistan. In the schema principle, the interpreter views in interpreting discourse like what had done by Ali Imron proof that his capability in decomposing word-meaning, but that he did not typically done in his normal understanding of sentences. In this case, Ali Imron's expressed his feeling through language to communicate what he purposed. The following example is the interesting statement of him :

Refer to this starting point, I felt to change my bad habits to be more better. And, I seriously want to devote and searching science. Besides, I also eager to fight islamic religion and muslim community from the evil of his enemy like what happened in Palestine and Afghanistan.

In the discourse, especially in the sentence ". . . I also eager to fight islamic religion and muslim community from the evil of his enemy like what happened in Palestine and Afghanistan" it shows how Ali Imron attitude was only taken for granted received an information. Eventually, his ambition was so high that was to fight islamic religion and muslim community.

Likewise, his following strory, stated that how his effort then was success when he had contacted Ali Ghufron whom was stayed in Malaysia. Therefore, Ali Imron got agreement and motivation from his old brother namely Ali Ghufron. Ali Imron's sentence structures below was represented his happiness mood :

My happiest moment was when I met with Ali Ghufron where I was never met him for six years. Eventually, Ali Ghufron was my nearest old brother since I was child. At the moment, I proposed my ambition to him in order to be searching science and went to Afghanistan like what he did,

In the story, the emotional moment in the discourse was when Ali Imron met with his old brother that is Ali Ghufron. Ali Imron, on his story said that since he was a child, he learned much the lessons from Ali Ghufron. After he grew up and matured, he decided and he wanted to join Ali Ghufron's. It had done by Ali Imron because he was absolutely sure to what Ali Ghufron did completely was right. What his belief was truely constructed by his memory and background knowledge to his old brother. However, Ali Imron did not understand about the changes of his old brother behaviour like his religious ideas orientation and affiliation of organization.

The fourth is Chain of events, it is the most part of which influential in making background knowledge of Ali Imron. On his empirical experience, since he was stayed in Afghanistan gave him real knowledge about the battlefield where he previously assumed it with jihad. In contrast, his knowledge was developed not just limited only to the war situation, but it widely to political constalation. Ali Imron's meeting with 
Syaikh Sayyaf and their dialogue about Taliban movement was a proof to the topic.

At that time, the Taliban movement appeared in Afghanistan which attacked everyone who did not want to join them. There were many news and issues about who they were. “. . . when I accompanied Abu Dujanah to meet Syaikh Abdur Robbi Rasul Sayyaf at Afghanistan's Tandzim Ittihad Islamic camp in Towrkham and I asked him about the Taliban group, but Syaikh Sayyaf only replied that the Taliban group were students just like you (like us). Knowing the issue and listening to Syaikh Sayyaf's answer made us a little confused and finally, we did not care about the Taliban group because the most important thing for us were to take care of the camp and running of the military programme".

In the discourse, Ali Imron really did not understand the chenge of political condition in Afghanistan. He was only adhered to what was said by Syaikh Sayyaf. His uncritical attitude to Syaikh Sayyaf replied and his ignorence to Taliban group attandence made him stayed at Afghanistan Military Camp steadily.

Eventhough he disatisfied to Syaikh Sayyaf answered but he had not done anything and he was keep going on military camp training. Although there is military attacked intimidation from Taliban group Ali Imron was the last man who left the military camp. In addition, this chain of events gave him additional belief to what he had done. It appears on his statement below :
At that moment, a short course war programme for our friends had been completed, and according to our leader no more friends would come to practice in Afghanistan. Moreover, there was information that the Taliban group will attack the Ittihad Islamic Tandzim Afghanistan camp in Towrkham where our camp was located. Therefore, our presence in Afghanistan was sufficiently considered, so that, one by one among of us went out from Afghanistan. In contrast, I and Harisah were the only last people who stayed there. And, at the end of 1995, we handed over the camp to the Ittihad Islamic Tandzim of Afghanistan. Furthermore, I and Harisah left Afghanistan to return back to Peshawar to join with Abu Dujanah, Sa'ad Al-Ghazi, and Shobih who stayed in the Representative Office in Pabbi.

His advanture in Afghanistan really was increased his confidence in war situation. It proof by his attitude to take over the camp. His understanding to the war reality phenomenon made him interprete his situation into two ways. They are 'Top-down and Bottom up' processing. In the part of the chain events discourse, Ali Imron constructed the meaning of jihad word and structure of his sentence to build up a composite meaning in order to equal with his reality. While at the same time, Ali Imron predicted the context of war with the additional composite meaning of what he had already known.

In similar way, Ali Imron's knowledge and his belief to jihad meaning was directly reached when he knew that the car brigade of Syaikh Sayyaf were attacked by the armed group of which according to Syaikh Sayyaf it had done 
by Taliban group. Refer to Syaikh Sayyaf explanation about the situation, finally, it would be able to growth hateness to America in Ali Imron's mind.

In the middle of 1992, Syaikh Abdur Robbi Rosul Sayyaf's convoy was attacked. Sayyaf's group departed from Afghanistan to Peshawar Pakistan to attend the graduation of the III class students of the Afghanistan Mujahidin Military Academy in the academic year 1991/1992. While in the middle of the trip, the group convoy were attacked by using anti-Tank weapons. The one of the convoy cars which rided by Hafidzul Haq (a commander of the subordinate Shaykh Sayyaf) was died on the attacked. On his funeral, Syaikh Abdur Robbi Rasul Sayyaf gave a speech and said that the attacked was masterminded by America and its alliences.

While the script, according to George Yule (1988: 241) revealed that a script is a part of the schema form which expressed or described of the sequence of events that describe a situation. In the following Ali Imron's statement it will directly find a conceptual dependency on his sentences. A conceptual dependency is a part of the script which demonstrate of the concepts which enter into relations described as dependencies.

Because of it was my own ambition to come to the place like that, so as it consequences I must to follow and obey all of the order eventhough it was so hard.

Refer to the sentence, the conceptual dependency of Ali Imron's sentence is clearly found on "... . it was my own ambition to come to the place like that ...". The phrase "the place like that', it can be interpreted as trouble, dangerous, and battlefiled place. To be able to interprete of the phrase like that, Shanks (1973: 201) claimed that it is the manifestation of an incorporation aspect of our knowledge of the world in his conceptual version of our understanding of sentence which would not be possible if his analysis operated with only the syntactic and lexical elements in the sentence. Therefore, Ali Imron's phrase on 'the place like that' it can be attached to the trouble, sadness, or dangerous concept of situation.

\section{Conclusion}

To conclude of this study, some significants analysis on Ali Imron's language comprehension in his life story appear both a schema and script of dimension in discourse analysis. The semantical problem, an understanding the setting, the mood, and the chain of events are the aspects of the background knowledge dimension of which attach on the schema of Ali Imron's memory. While the script which demonstrate on Ali Imron's language is the conceptual dependency where it means his conceptual understanding on the sentence and lexical elements are incorporated with his knowledge.

Finally, the backgruond knowledge can lead to errors in understanding and it appears to what happened to Ali Imron's understanding in interpreting the word of jihad and its conceptual meaning. What does mean with error understanding and interpreting are that the religious language of which Ali Imron uses its words are contain borrowing language. So, it needs complicated process to transform it to Bahasa Indonesia (Indonesian Language) and to Ali Imron's cultural background. In fact, in arabic the words like jihad, muhajir, and syahid are have several dimensions as a language 
meaning and it can be conceptual in as meaning and an abstract as a form.

\section{REFERENCES}

Assyaukanie, Luthfi. The Diffusion of Middle-Eastern Radicalist Ideas to Indonesia. Jurnal Substansia, Vol. 1, No. 1, Maret 2009.

Abou El Fadl, Khaled (2005). The Great Theft Wrestling Islam From The Extrimists. Perfectbound, HarperSanFransisco.

Bartlett, Frederic (1932). Remembering. Cambridge: Cambridge University Press.

Brown, Gillian and George Yule (1988). Discourse Analysis. Cambridge: Cambridge University Press.

Creswell, John W. (2007). Qualitative Inquiry \& Research Design. London: SAGE Publications.

Firestone, Reuven. (1999). Jihad The Origin of Holy War in Islam. Oxford: Oxford University Press.

Hwang, Julie Chernov (2018). Why Terrorist Quit. Ithaca and London: Cornell University Press.

Imron, Ali (2007). Ali Imron Sang Pengebom. Jakarta: Republika.

Jupp, Victor (2006). The SAGE Dictionary of Social Research Methods. London: SAGE Publications.

Shanks, R. C. \& K. M. Colby (1973). Computer Models of Thought and Language. San Francisco: Freeman.

Schmid, Alex P. (ed.) (2011). The Routledge Handbook of Terrorism Research. New York: Routledge.

Yule, George (2010). The Study of Language. Cambridge:

Cambridge University Press. 